\title{
IdENTIFICATION OF Mid-SPATIAL FreQUenCy ERror ON THE OPTOTECH MCG 100 WHEN GRINDING OPTICAL ELEMENTS
}

\author{
Jiř́i Beneš ${ }^{1}$; Michal Špína ${ }^{2} ;$ František Procháska ${ }^{3}$ \\ Institute of Plasma Physics, Academy of Sciences of the Czech Republic, \\ Regional Centre for Special Optics and Optoelectronic Systems (TOPTEC), \\ Sobotecká 1660, 51101 Turnov, Czech Republic \\ e-mail: ${ }^{1}$ benes@ipp.cas.cz; ${ }^{2}$ spina@ipp.cas.cz; ${ }^{3}$ prochaska@ipp.cas.cz
}

\begin{abstract}
The mid-spatial frequency errors, surface defects arising from the production of optical aspherical surfaces may be a major problem, for example in high-performance systems. At the production of aspherical surfaces on the Optotech MCG100, vibration measurements were performed in various operating modes. The measurement was done with VibXpert II. This device uses piezoelectric sensors to record vibration acceleration. The measurement data were then processed in Matlab software. The aim was to identify frequencies, which may have a negative influence on optical element manufacturing, and also to outline possible causes of their origin.

In the observed spectrum $(30-800 \mathrm{~Hz})$, significant frequencies from several basic sources were found. This is the tool spindle rotation, tool rotation, the axes control loop, and the movement of the axes themselves.
\end{abstract}

\section{Keywords}

Vibration; Middle; Frequency; Optical; Aspheric; Surface.

\section{Introduction}

Vibrations in CNC machines are a complex phenomenon. They are caused by interactions between the solid and flexible elements constituting the machine. These vibrations may be caused by imbalance of rotating parts, inertia forces of elements performing a direct or circular reciprocating motion, imprecision of transmission mechanisms, or by background interference via the base to the machine.

For optical fine grinding, vibration is a major obstacle to achieving the required quality. Transmission of vibration into process means deformation of the optical surface. This has a negative effect on the transmission of light through the optical element and creates a defect in the image.

\section{$1 \quad$ Research Objectives}

The aim of the research is to investigate the occurrence of mid-spatial frequency errors and to propose methods for their suppression. These defects are due to vibrations (Figure 1). These vibrations are transmitted to the optical surface in the form of a regular local shape defect. The defect thus created adverse effects on the entire optical system. So we have tried to find out the causes of the vibrations and tried to design a way to reduce these vibrations. 


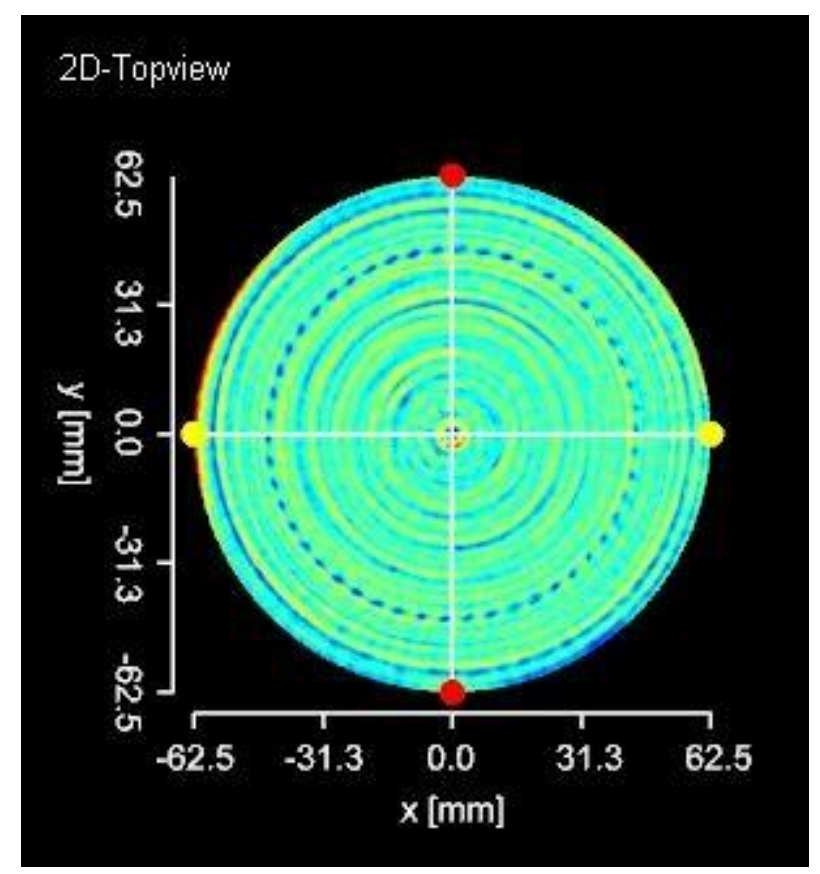

Source: Own

Fig. 1: An example of mid-spatial frequency error

\section{$2 \quad$ Methods of Research}

The basic source of mid-spatial frequency error is the grinding process. During this process, defects occur on the optical surface, which is very difficult to suppress in the later stages of machining. The entire grinding process is performed on an Optotech MCG 100 machine where the occurrence of these defects was observed earlier. The whole process is divided into several basic stages. First, rough and fine grinding. Second, ultra fine grinding, and the last are corrections. Grinding involves the removal of four layers, followed by a profile measurement on the LUPHOScan contactless profilometer. The measured data are then used to correct the optical deflection of the optical surface. This step is performed by removing two layers. The diamond tools are used with $100 \mathrm{~mm}$ diameters and grains D91, D38 with a metal bond and D20 with a resin bond. During the grinding process, vibration acceleration is measured with the VibXpert II. The measuring instrument uses a pair of piezoelectric sensors mounted on a magnet. These sensors are mounted on the rotating head of the tool spindles (Figure 2) in the Y direction. From the measured data, FFT frequency analysis is then created in Matlab software. 


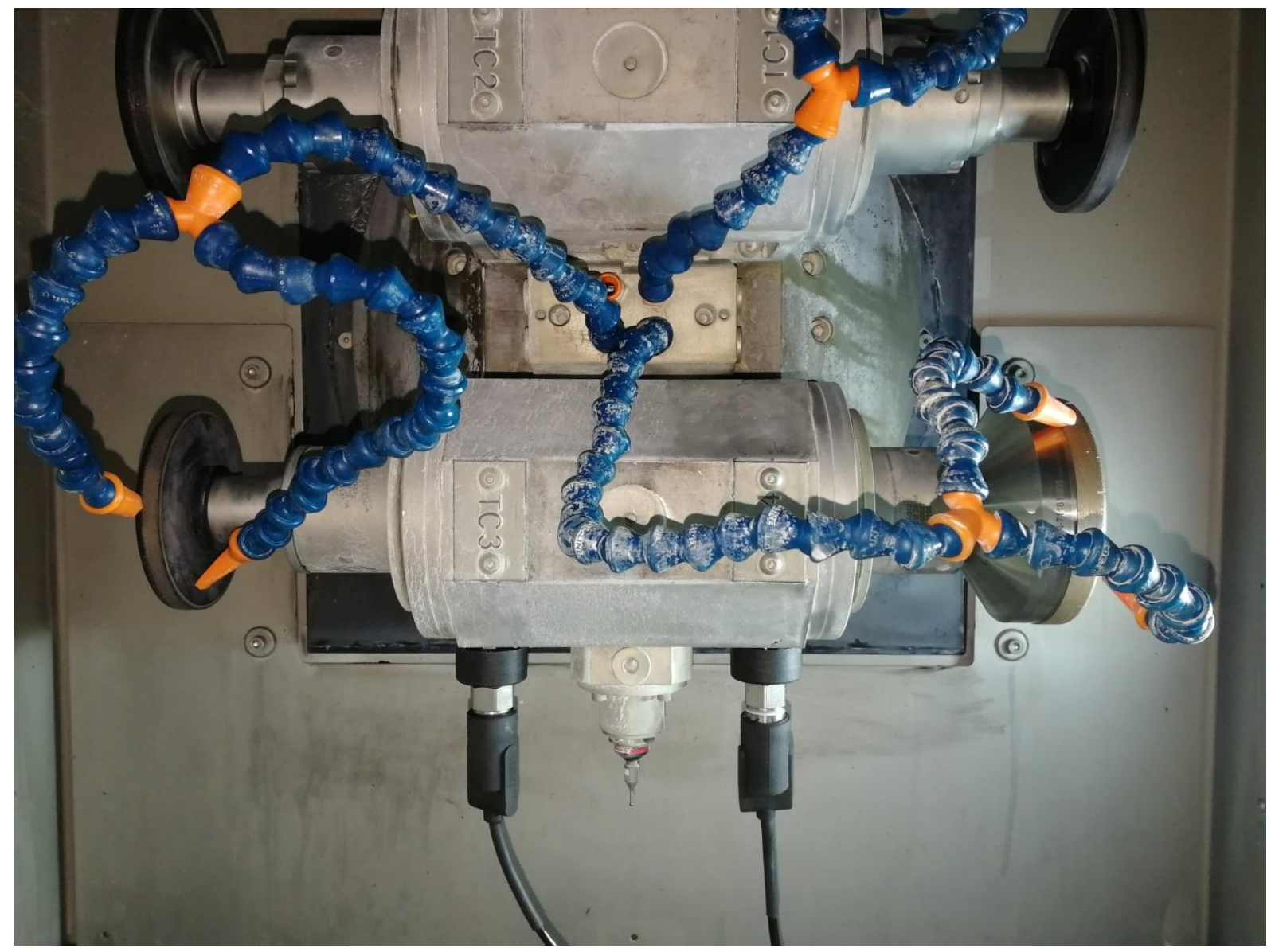

Source: Own

Fig. 2: Sensors mounted on the rotating head of the tool spindles

\section{$3 \quad$ Mid-spatial Frequency}

Mid-spatial frequency errors include structures with wavelength of $0.46-10 \mathrm{~mm}$. The wavelength of the structures in the concentric direction is determined by the circumferential workpiece velocity and the frequency of undesirable vibrations (1). For a circumferential velocity $v_{o}=20 \mathrm{~m} / \mathrm{min}$ it is approximately $33-724 \mathrm{~Hz}$.

$$
\lambda=\frac{v_{0}}{f}
$$

\section{$4 \quad$ Identification of Key Frequencies and Potential Vibration Sources}

Research into vibration sources in this range revealed several factors. To enable identification of specific vibration sources, the experiment was begun by a measurement of vibrations in different modes of the machine. The first measurement was carried out on a switched-off machine. Thus, we acquired an indication of interference (Figure 3). [1] 


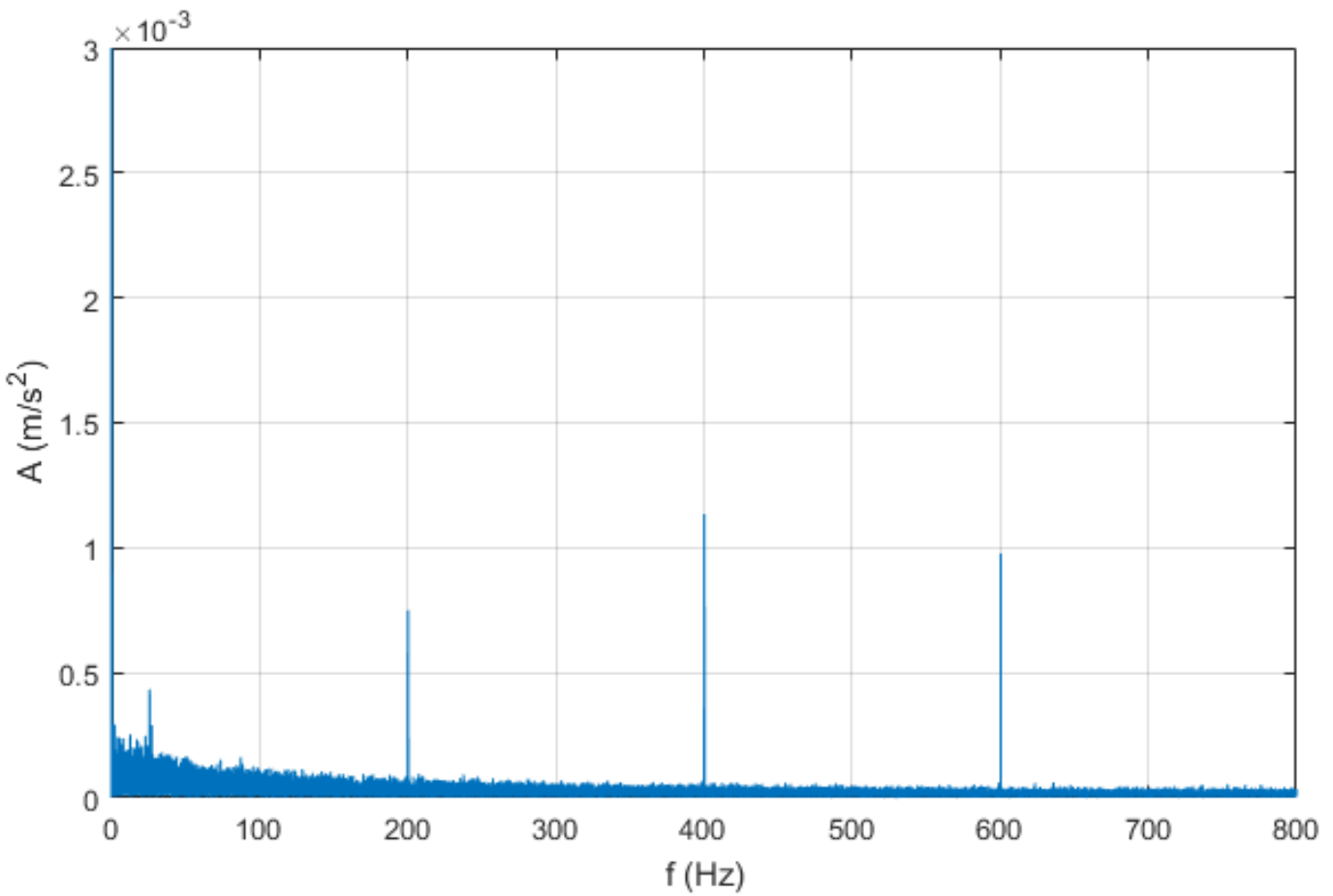

Source: $O w n$

Fig. 3: Frequency analysis of vibration acceleration measurement on a switched-off machine

In a resting-state mode, once the machine was switched on (Figure 4), frequencies of 50 and $100 \mathrm{~Hz}$, which are attributed to the operating system of the machine, were revealed in addition to the above-described interferences.

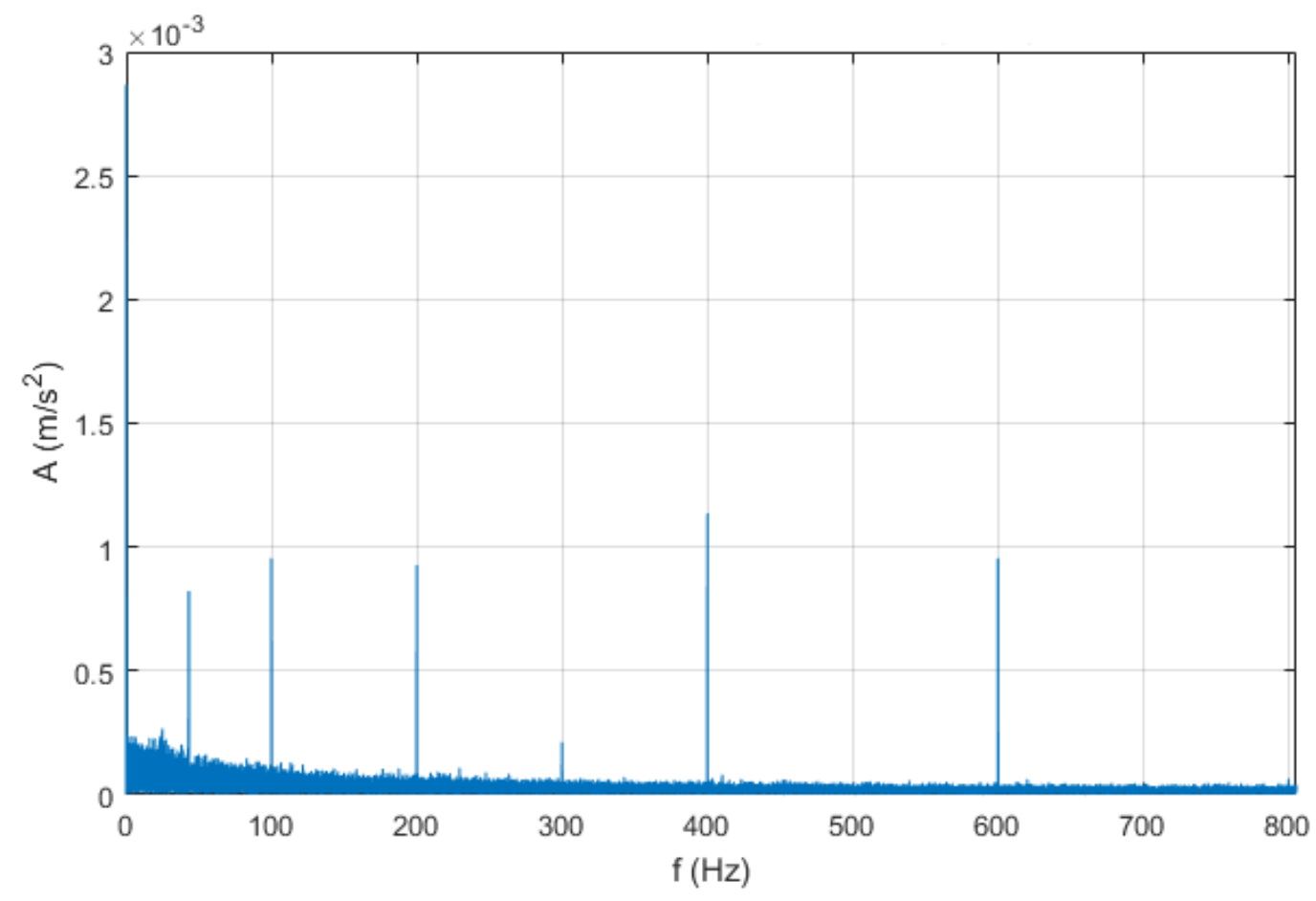

Source: Own

Fig. 4: Frequency analysis of vibration acceleration measurement upon switching on electric current 
Next, the measurement was completed during a running process, in which workpiece and tool drives were deactivated, as were linear axes motions (Figure 5). The measurement showed that, in addition to the previously discovered frequencies, this mode generated a number of others. Given the mode of the machine, these frequencies are primarily ascribed to the axes positioning system or more precisely to regenerative loops, which ensure precise positioning of the axes. While these loops operate at a much higher frequency (around $4 \mathrm{kHz}$ ), they generate frequencies near 200 and $600 \mathrm{~Hz}$ in the mechanical system of the machine. [1][5]

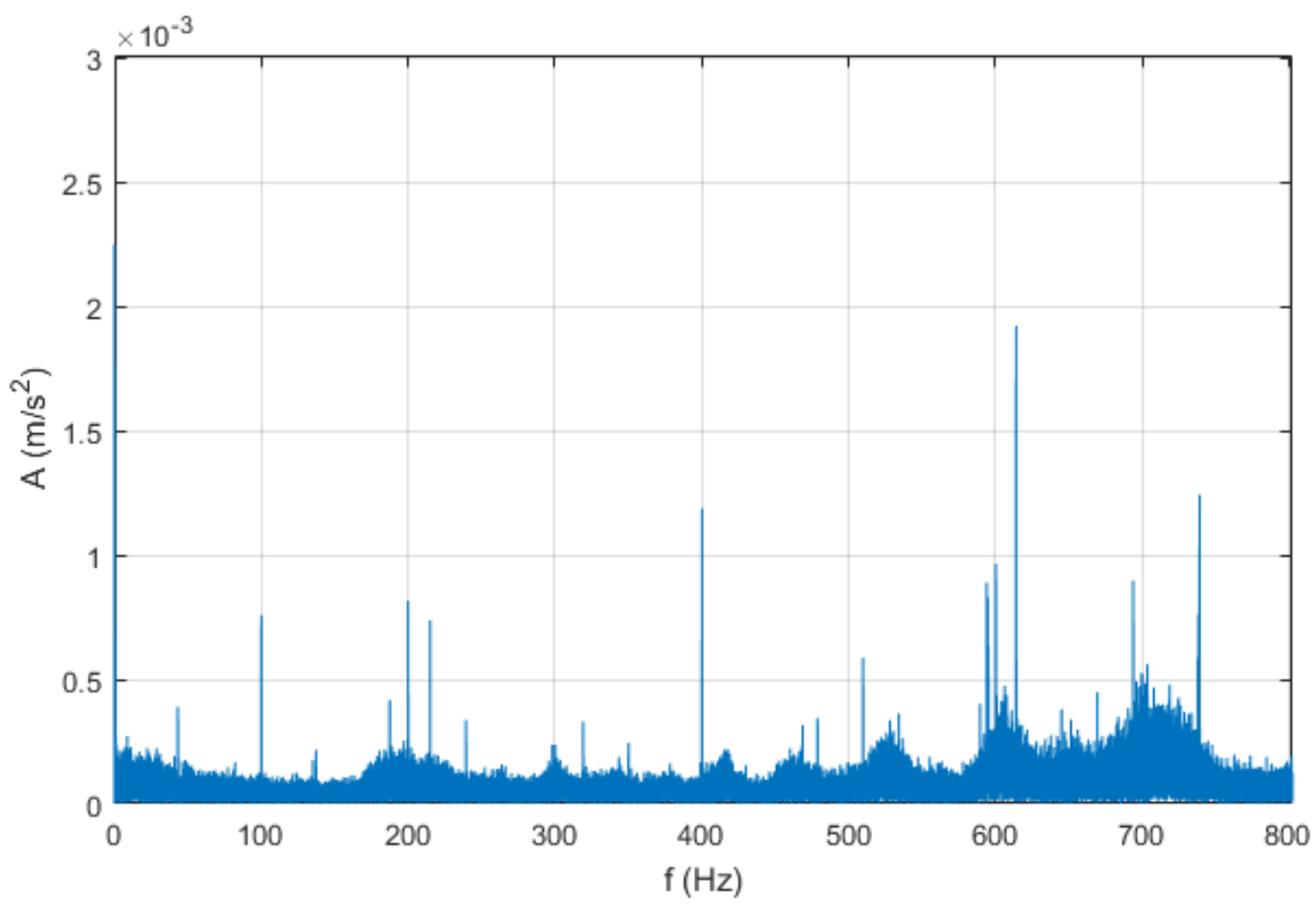

Source: Own

Fig. 5: Frequency analysis of vibration acceleration measurement during a running process, tool rotation and axes motion deactivated

Following activation of axes motion (Figure 6), multiple frequencies in the whole monitored frequency range appear. However, their amplitude remains very low.

In the last two experiments, the influence of the rotation of the tool spindle was tested. First, a measurement was carried out with the tool removed. It became apparent that the spindle itself, or more precisely the driving electric motor and bearings defining the axis, present a significant source of vibrations (Figure 7). Compared to the previous experiments, there is a marked increase in the amplitudes of certain specific frequencies. These are frequencies generated by the rotation itself (main rotation frequency $69.5 \mathrm{~Hz}$ and harmonic frequency $139 \mathrm{~Hz})$ and frequencies created on the bearing fit of the axis $(652$ and $738 \mathrm{~Hz})$. The frequencies observed in the previous measurements have also shown a moderate growth. [1][5] 


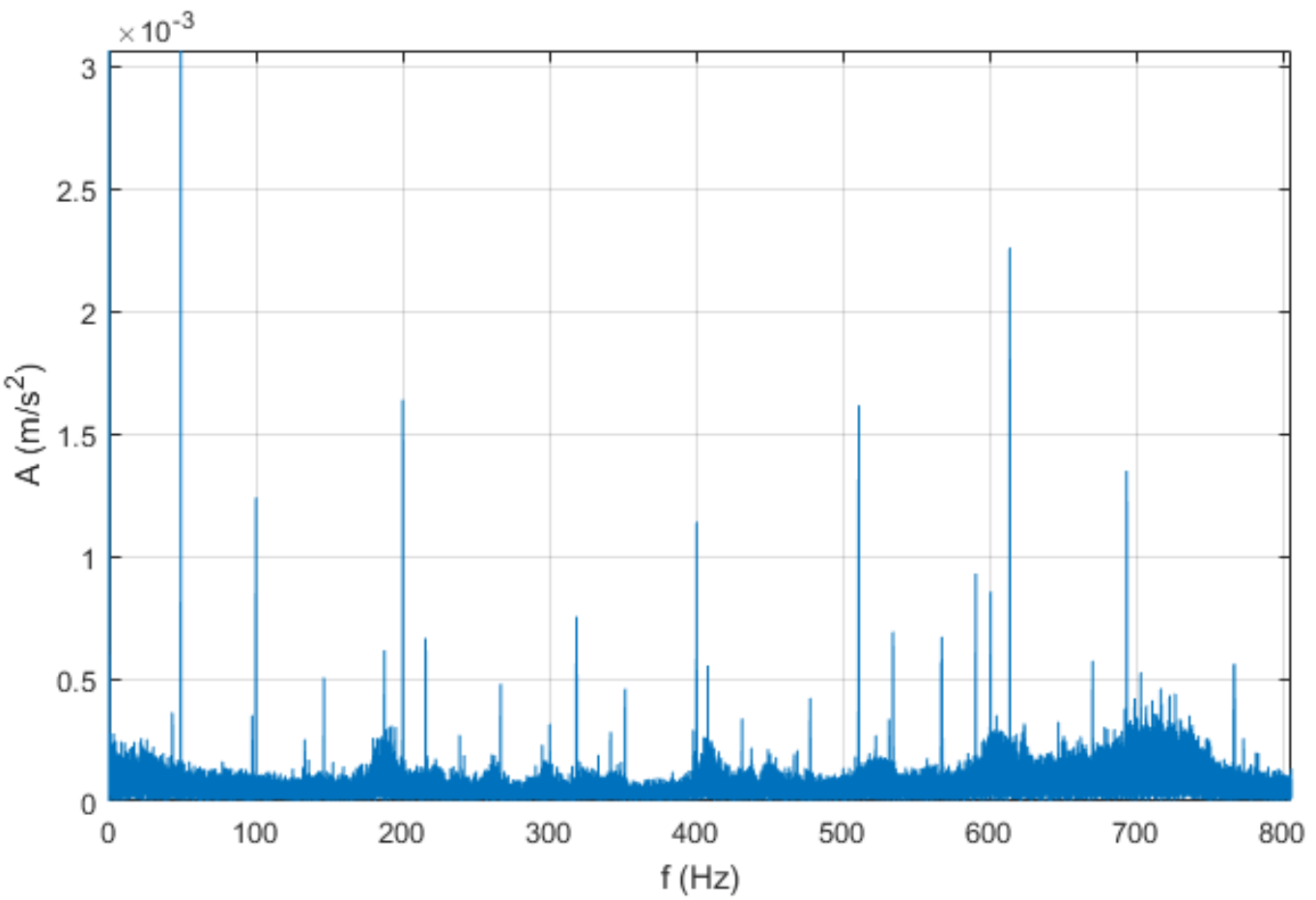

Source: Own

Fig. 6: Frequency analysis of vibration acceleration measurement following process initiation, tool rotation deactivated, axes motion active

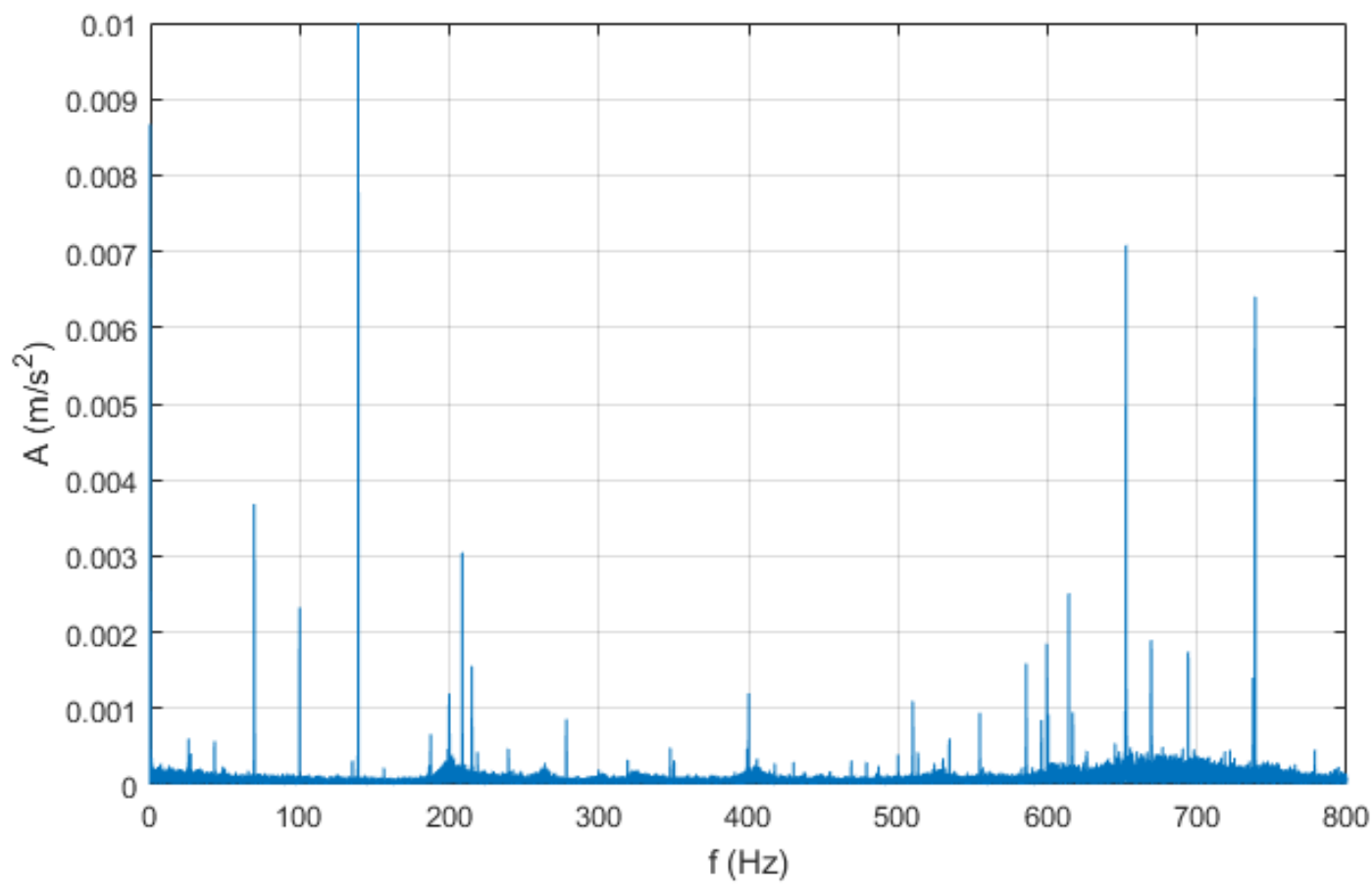

Source: Own

Fig. 7: Frequency analysis of vibration acceleration measurement during the tool spindle rotation (without the tool)

With the tool attached, amplitudes of 69.5 and $139 \mathrm{~Hz}$ frequencies rise moderately (most likely due to a slight unbalance of the tool) and amplitudes of 652 and $738 \mathrm{~Hz}$ grow almost 
threefold. This phenomenon is attributed to the change in weight distribution on the spindle caused by the attachment of the tool (Figure 8).

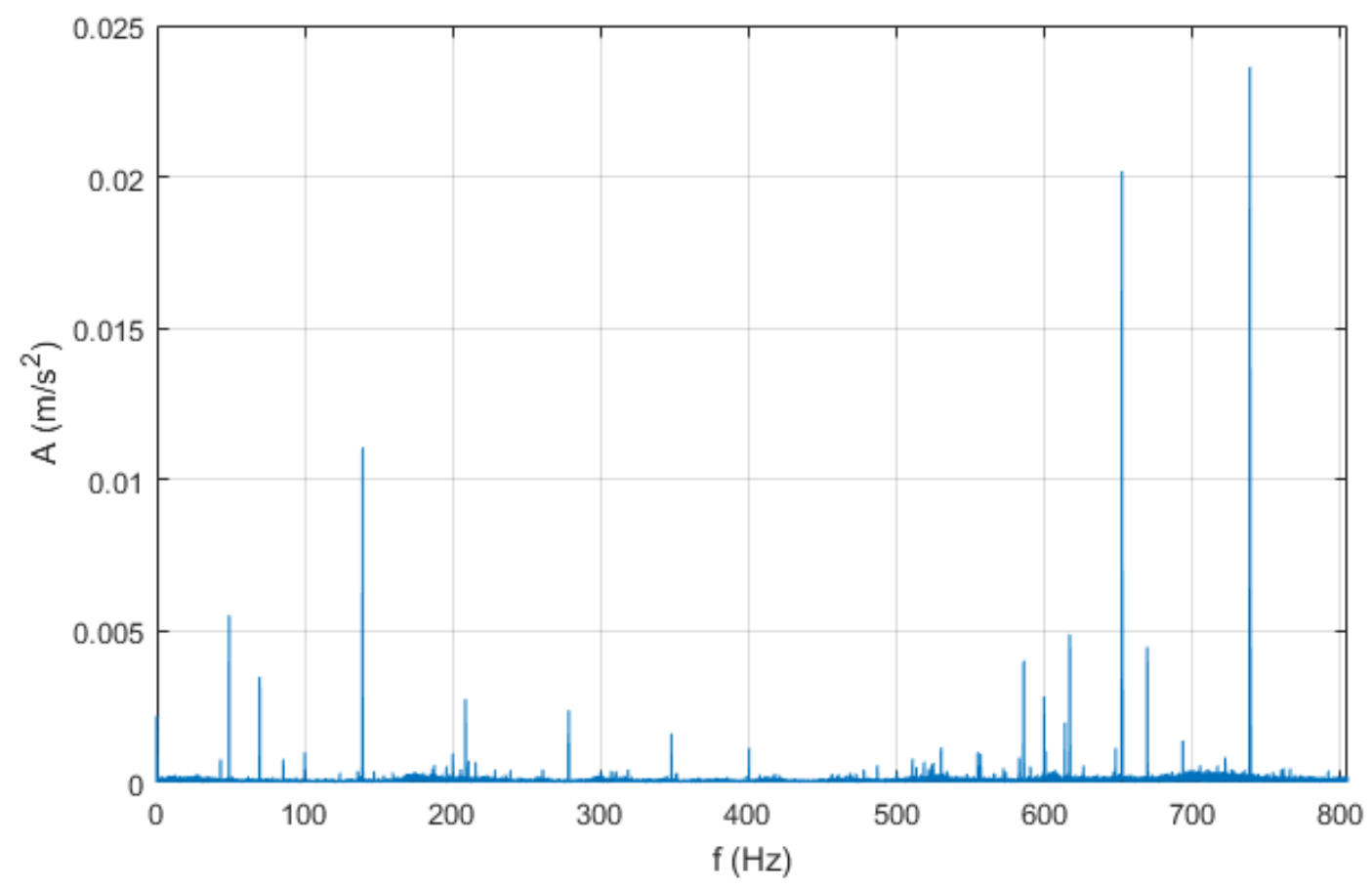

Source: Own

Fig. 8: Frequency analysis of vibration acceleration measurement during the tool spindle rotation (with the tool attached)

\section{$5 \quad$ Vibration Monitoring During Real Grinding Process}

In the second phase, experiments were performed on actual grinding processes. Primary experiments were conducted on horizontal planes, where the generated artifacts could be measured and examined more precisely. In these experiments, two different cutting speeds of the tool were tested during otherwise identical processes. It was discovered that a large number of the frequencies detected in the previous experiments are suppressed during the machining itself. This is ascribed to the impact of the tool on the workpiece, i.e. to the rigidity of the axes and to the forces produced during the process.

The individual measurements show that in the monitored frequency range there appear frequencies corresponding with the revolutions of the tool (they change with the tool revolutions) as well as frequencies in the $500-800 \mathrm{~Hz}$ range, which are caused by the mechanical core of the machine (they remain constant despite a change in revolutions). An example of a graph depicting the machining process, i.e. the dependence of individual frequency amplitudes on the medial distance on the machined surface, is shown in Figure 9. 


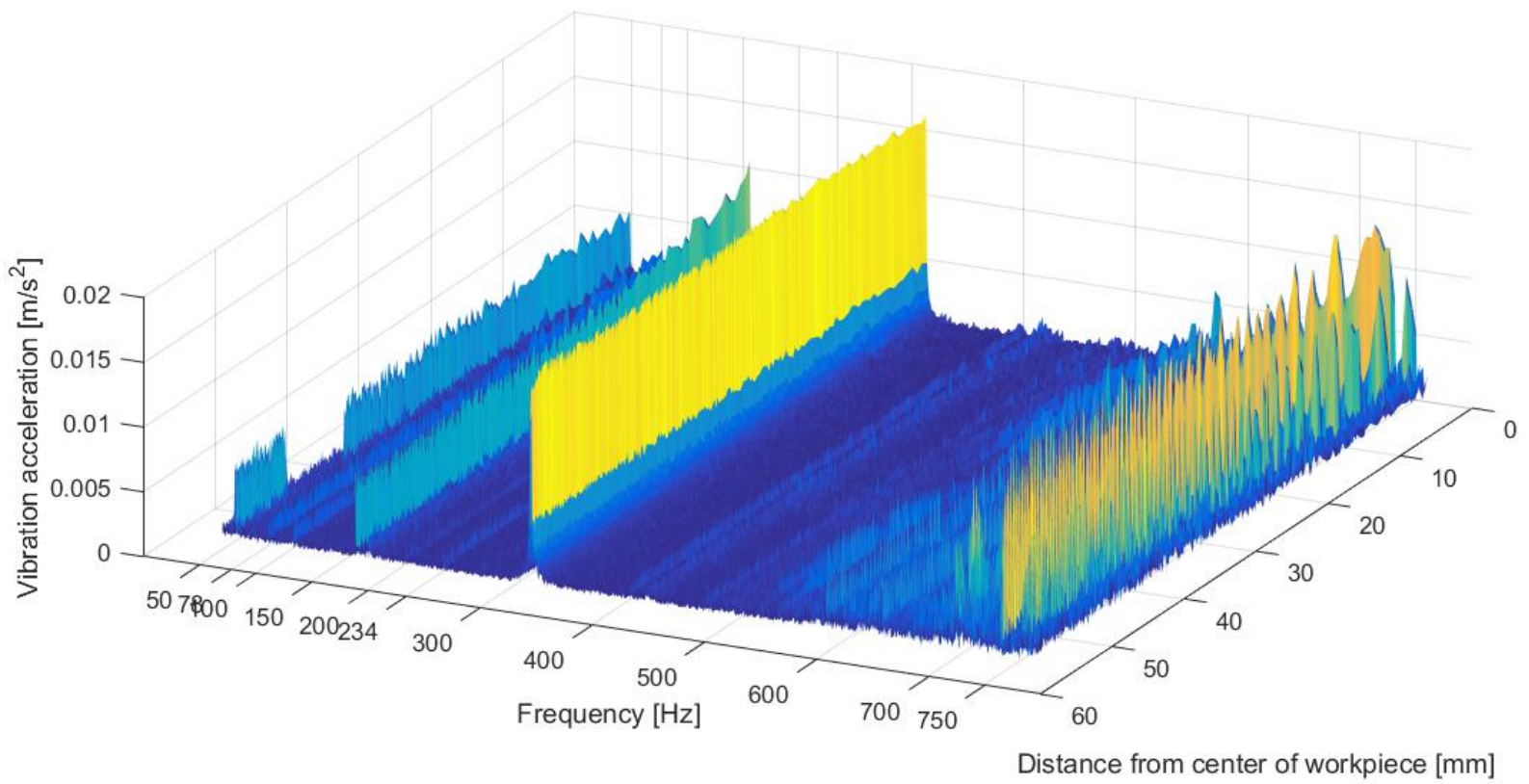

Source: Own

Fig. 9: Frequency analysis of measurement during an actual process of horizontal plane grinding (cutting speed $24 \mathrm{~m} / \mathrm{s}$ )

The last step was to test if changes in process behavior occur during grinding of nonhorizontal planes. Experiments conducted on several types of aspheric surfaces revealed that the processes behave in very similar ways. Figure 10 shows marked amplitude of toolgenerated frequencies as well as of frequencies in the aforementioned $500-800 \mathrm{~Hz}$ range.

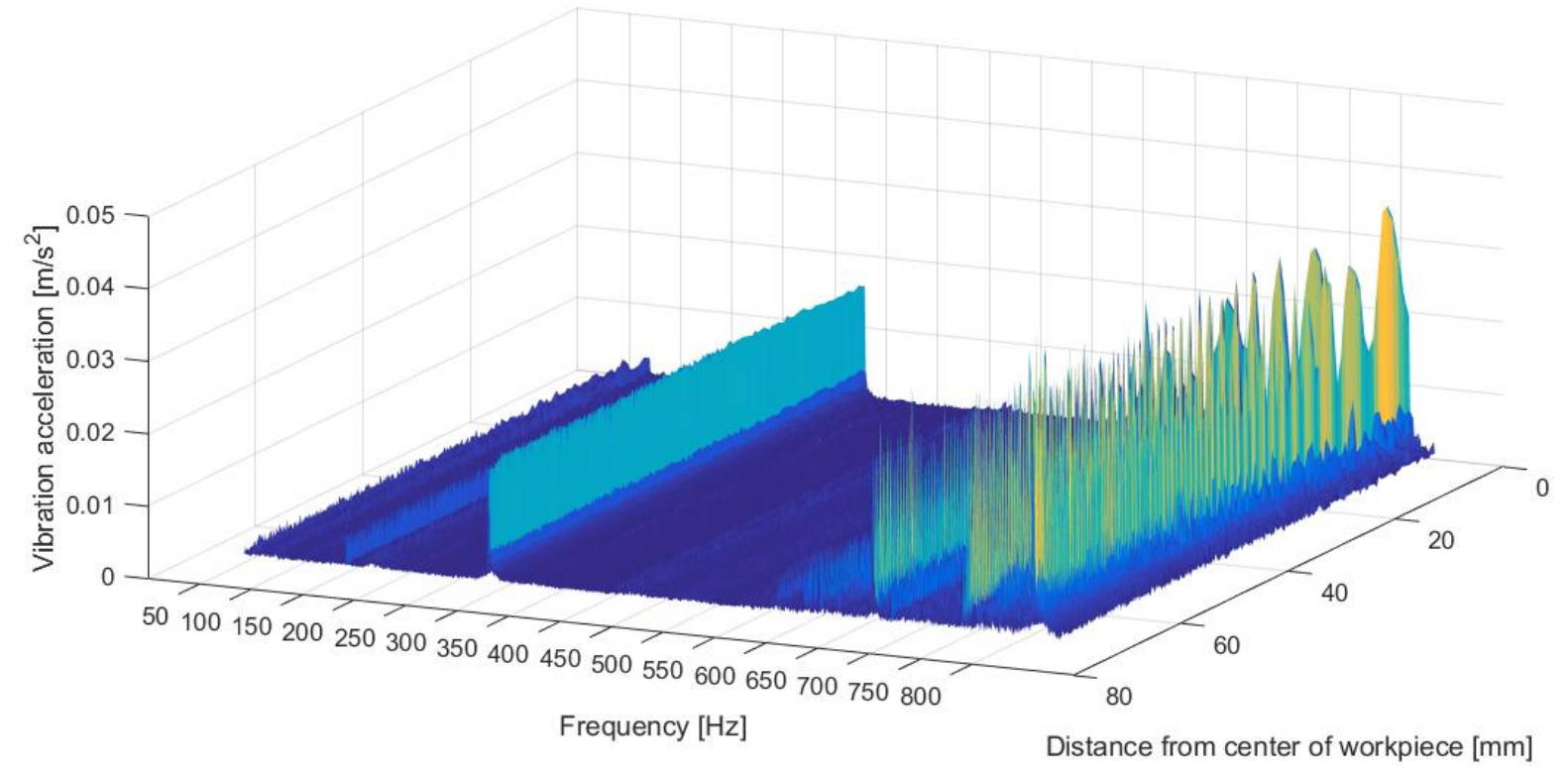

Source: Own

Fig. 10: Frequency analysis of measurement during an actual process of aspheric surface grinding (cutting speed $20 \mathrm{~m} / \mathrm{s}$ )

\section{$6 \quad$ Vibration Suppression Options}

Frequencies occurring in the $50-500 \mathrm{~Hz}$ range due to the tool speed could be partially suppressed by balancing the tool. This method is useful for tools that have stable properties 
over time. Therefore, for metal bonded tools there is no need for frequent maintenance (change of tool properties). For resin-bonded tools, this method is not suitable. [3][4]

Another option to partially suppress frequencies of $50-500 \mathrm{~Hz}$ is machine maintenance specifically of the bearings on the tool axis. The measured data indicate a certain wear rate on bearings and their service could be used to suppress vibrations generated by tool rotation. This service may also have a positive effect on suppression of frequencies of $500-800 \mathrm{~Hz}$. The last proposed solution is adding load to the $\mathrm{Y}$ axis. This should change the way the vibration propagates and shifts it out of the critical area.

\section{Conclusion}

During the experiments, it was found that vibrations from three basic sources affected the machining process. They are the rotation of the tool spindle, axis positioning system, and axis movement. A great deal of blame for these sources is the wear of the machine tool. Therefore, service was designed to solve these problems, which could greatly help to suppress these unfavorable influences.

\section{Acknowledgements}

This work was supported by the Ministry of Education, Youth and Sports of the Czech Republic in the project NPU no. LO1206 and by the Ministry of Industry and Trade in the project "Avoiding and removing mid-spatial frequency errors in asphere and free form fabric" with No. CZ.01.1.02/0.0/0.0/15_019/0004798.

\section{Literature}

[1] JANÍČKOVÁ, P.: Moderní konstrukční řešení. [Online] 2010. [accessed 2018-12-04] Available from WWW: http://www.uh.cz/szesgsm/files/sblizovani/pdf/mod-konstrcnc.pdf

[2] MELOUN, M.; MILITKÝ, J.: Statistická analýza experimentálních dat. Praha: Academia, 2004. ISBN 80-200-1254-0.

[3] SUCHNA K.: Jednoduché vyvažování nástrojů. MM Pri̊myslové spektrum. [Online] [accessed 2018-12-04] Available from https://www.mmspektrum.com/clanek/jednoduche-vyvazovani-nastroju.html

[4] SHAFRIR, S. N.: Diamond Tool Wear - Observation by Scanning Electron Microscopy (SEM). [Online] [accessed 2018-12-04] Available from WWW: http://www.optics.rochester.edu/workgroups/cml/opt307/spr04/shai/index.html

[5] HELEBRANT, F.; ZIEGLER J.: Technická diagnostika a spolehlivost. Ostrava: VŠB Technická univerzita, 2004. ISBN 9788024806501.

Ing. Jiří Beneš; Ing. Michal Špína; Ing. František Procháska, Ph.D. 


\section{IDENTIFIKACE STŘEDNÍCH PROSTOROVÝCH FREKVENCÍ PŘI OBRÁBĚCÍM PROCESU NA OPTOTECH MCG 100}

Střední prostorové frekvence, povrchové vady vznikající při výrobě optických asférických ploch, mohou být velkým problémem např. ve vysoce výkonných optických systémech. Při výrobě asférických ploch na stroji Optotech MCG100 bylo proto provedeno měření vibrací $\mathrm{v}$ různých režimech chodu měřicím zařízením VibXpert II. Toto zařízení pomocí piezoelektrických snímačů zaznamenává zrychlení vibrací. Data z měření byla následně zpracována v softwaru Matlab. Cílem bylo identifikovat frekvence, které mohou nepř́iznivě ovlivňovat výrobu optických elementů a dále nastínit možné př́činy jejich vzniku.

Bylo zjištěno, že ve sledovaném spektru $33-800 \mathrm{~Hz}$ se vyskytují výrazné frekvence z několika základních zdrojů. Jedná se o rotaci nástrojového vřetena, o rotaci nástroje, regulační smyčku pohybu os a samotný pohyb os.

\section{IDENTIFIZIERUNG MITTLERER RÄUMLICHER FREQUENZEN BEIM FRÄSPROZESS MIT DEM OPTOTECH MCG 100}

Die mittlere räumliche Frequenz und Oberflächenschäden, welche bei der Produktion optischer asphärischer Flächen entstehen, können ein großes Problem z. B. bei hoch leistungsfähigen optischen Systemen darstellen. Bei der Produktion asphärischer Flächen auf der Maschine Optotech MCG100 wurde daher eine Messung der Vibrationen in verschiedenen Arbeitsabläufen mit Hilfe der Messeinrichtung VibXpert II durchgeführt. Diese Einrichtung zeichnet mit Hilfe piezoelektrischer Sensoren die Beschleunigung der Vibrationen auf. Die Messdaten wurden im Anschluss mit der Software Matlab verarbeitet. Ziel war die Identifizierung der Frequenzen, welche die Produktion optischer Elemente ungünstig beeinflussen und Hinweise auf weitere mögliche Ursachen von deren Entstehung geben können.

Es wurde festgestellt, dass im beobachteten Spektrum $33-800 \mathrm{~Hz}$ deutliche Frequenzen aus mehreren Quellen auftreten. Es handelt sich um die Rotation der Instrumentenspindel, um die Rotation der Regulationsschleife der Achsenbewegung und die eigentliche Achsenbewegung.

\section{IDENTYFIKACJA ŚREDNICH CZĘSTOTLIWOŚCI PRZESTRZENNYCH W PROCESIE OBRÓBKI NA URZĄDZENIU OPTOTECH MCG 100}

Średnie częstotliwości przestrzenne, wady powierzchniowe powstające w procesie produkcji optycznych powierzchni asferycznych mogą stanowić duży problem w bardzo wydajnych systemach optycznych. Podczas produkcji powierzchni asferycznych na maszynie Optotech MCG100 wykonano więc pomiaru wibracji dla różnych trybów pracy urządzenia. Pomiary wykonano urządzeniem VibXpert II. Przy pomocy czujników piezoelektrycznych urządzenie to odnotowuje przyspieszenie wibracji. Następnie dane $\mathrm{z}$ pomiaru opracowano w oprogramowaniu Matlab. Celem było zidentyfikowanie częstotliwości, które mogą mieć niekorzystny wpływ na produkcję elementów optycznych oraz wskazanie możliwych przyczyn ich powstania.

Stwierdzono, że w analizowanym spektrum 33-880 Hz występują wyraźne częstotliwości pochodzące z kilku źródeł podstawowych. To rotacja wrzeciona urządzenia, rotacja urządzenia, pętla regulacyjna ruchu oraz własny ruch osi. 